\title{
Sheep preference for leafy spurge from Idaho and North Dakota
}

\author{
SCOTT L. KRONBERG AND JOHN W. WALKER
}

Authors are associate professor, Department of Animal \& Range Sciences, South Dakota State University, Brookings, SD 57007-0392 and research director and range scientist, Texas A\&M University Agricultural Research and Extension Center, San Angelo, Texas 76901 . Both authors were with the USDA-ARS, U.S. Sheep Experiment Station, HC 62, Box 2010, Dubois, Idaho 83402 when the trials were conducted for this research.

\begin{abstract}
Three trials were conducted to determine if low ingestion of some leafy spurge (Euphorbia esula $\mathbf{L}$.) by sheep is primarily due to differences in sheep or in leafy spurge. In the first trial, pastures in Idaho and North Dakota were grazed by sheep originating from both states. Generally, sheep from both states grazed the leafy spurge growing in the Idaho pastures reluctantly but grazed the leafy spurge growing in the North Dakota pastures in proportion to its availability $(P=\mathbf{0 . 0 0 3})$. In the second trial, ingestion of air-dried leafy spurge by penned sheep was compared by offering samples from the 2 locations simultaneously. Sheep consumed more $(P=0.0001)$ leafy spurge from North Dakota than from Idaho. In the third trial, penned sheep were simultaneously offered Idaho leafy spurge harvested from fertilized and non-fertilized sites. Initially, equal amounts of fertilized and unfertilized leafy spurge were consumed $(P \geq .68)$, but by the fourth day sheep had an obvious preference for leafy spurge from the fertilized site $(P=0.01)$. These trials indicate that preference for leafy spurge by sheep differs depending on site, and that using sheep to manage leafy spurge may be more successful on soils with relatively high fertility.
\end{abstract}

Key Words: diet selection, palatability, noxious weeds, Euphorbia esula

Sheep and goats are used to help control and utilize the weed leafy spurge (Euphorbia esula L.) in many western states and Canadian provinces (Johnston and Peake 1960, Landgraf et al. 1984, Bartz et al. 1985, Faller et al. 1995). However, we have observed that the palatability of leafy spurge to sheep may vary among range sites. This could result from differences among animals, from differences in the environments where leafy spurge grows, from different

\footnotetext{
Acknowledgments: We thank T. Faller for supplying sheep from North Dakota and reviewing the manuscript, J. Hopkins for nutritional analysis of leafy spurge samples and D. Swanson for technical assistance in Idaho. We thank the following individuals for their help in North Dakota: J. Bosworth for assisting with the grazing trial and harvesting leafy spurge, P. Hesch for assisting with the grazing trial, L. Hofmann for collecting soil samples and R. Lorenz for arranging the use of the grazing site. We appreciate suggestions for revisions to the manuscript made by $\mathrm{P}$. Johnson, M. Ralphs and anonymous reviewers, and Juan Villalba's translation of the abstract into Spanish.

Manuscript accepted 10 Apr. 1998
}

\section{Resumen}

Con el objeto de determinar si la baja ingestión de "leafy spurge" (Euphorbia esula L.) por parte de ovinos es debida principalmente a diferencias en ovinos o en "leafy spurge" se realizaron tres ensayos. En el primer ensayo, pasturas de Idaho (ID) y de Dakota del Norte (ND) fueron pastoreadas por ovinos originarios de ambos estados. En general, ovinos de ambos estados pastorearon renuentemente "leafy spurge" que creció en las pasturas de ID pero pastorearon "leafy spurge" que creció en las pasturas de ND en proporción a su disponibilidad $(P=0.003)$. En el segundo ensayo, se comparó la ingestión de "leafy spurge", secada en corriente de aire forzado, por parte de ovinos en corrales que recibieron muestras de los dos lugares simultaneamente. Ovinos consumieron mas $(P=0.0001)$ "leafy spurge" originaria de ND que "leafy spurge" originaria de ID. En el tercer ensayo, ovinos en corrales recibieron una oferta simultanea de "leafy spurge" originaria de ID cosechada en lugares fertilizados y no fertilizados. Inicialmente fueron consumidas cantidades iguales de "leafy spurge" fertilizada y no fertilizada $(P \geq .68)$, pero al cuarto dia los ovinos tuvieron una obvia preferencia por "leafy spurge" proveniente del lugar fertilizado $(P=0.01)$. Estos ensayos indican que la preferencia por "leafy spurge" en ovinos difiere dependiendo del sitio de establecimiento, y que el uso de ovinos para el manejo de "leafy spurge" puede ser mas exitoso en suelos con relativamente alta fertilidad.

plant phenotypes and chemical contents, or perhaps from interactions among these factors.

Several factors may account for differences in animal preference for leafy spurge. These include degree of previous experience with leafy spurge (Walker et al. 1992, Olson et al. 1995), whether individuals were exposed to leafy spurge when young or as adults (Squibb et al. 1990, Provenza et al. 1992), genotypic and consequently physiological differences among individual animals (Provenza 1995), and differences in the relative palatability of alternative vegetation to the animals. In a paired-choice study, goats preferred leafy spurge when it was offered with arrowleaf balsamroot (Balsamorhiza sagittata (Pursh) Nutt.) but preferred crested wheatgrass (Agropyron crista- 
tum (L.) Gaertn.) when it was offered with leafy spurge; sheep preferred both of these alternative plants when they were paired with leafy spurge. In southeastern Idaho, goats showed a relative preference for grazing leafy spurge while sheep avoided this plant (Walker et al. 1994).

Leafy spurge can elicit aversive feeding responses in cattle, sheep, and goats. This, response was strongest in cattle and weakest in goats with sheep intermediate (Kronberg et al. 1993, 1994). Also, individual sheep and goats vary in their tolerance for the aversive chemical(s) in leafy spurge (Kronberg and Walker, unpublished data).

Levels of aversive and other defensive phytochemicals can vary within a plant species as a function of soil fertility and shading (Bryant et al. 1983, 1991, Mihaliak and Lincoln 1985, Mihaliak et al. 1987, Fajer et al. 1992, Ruohomki et al. 1996). Carbon-based phytochemicals tend to occur at higher concentrations in plants that grow in infertile soils. Additionally, plant/water relations can affect levels of defensive phytochemicals (Briske and Camp 1982, Vrieling et al. 1993). Variability in phytochemical concentration can also have a genetic component (Fajer et al. 1992, Vrieling et al. 1993, Ruohomki et al. 1996). Leafy spurge has considerable genetic variability (Nissen et al. 1992); however, chloroplast DNA analysis of leafy spurge from our Idaho study site indicated that this leafy spurge is genetically similar to leafy spurge collected in North and South Dakota and Nebraska (Nissen, personal communication).

We conducted 3 trials to elucidate aspects of sheep response to leafy spurge. The overall objective of these trials was to determine if preference for leafy spurge differs because of sheep origin and (or) site location.

\section{Material and Methods}

\section{Trial 1}

A grazing trial was conducted to determine if relative preference by sheep for leafy spurge differed in Idaho and North Dakota. The trial was conducted on leafy spurge-infested pastures near Dubois, Ida. and Bismark, N.D. The Idaho pastures were $17 \mathrm{~km}$ northwest of Dubois $\left(112^{\circ}\right.$ $\left.22^{\prime} \mathrm{W}, 44^{\circ} 15^{\prime} \mathrm{N}\right)$ on stream terrace near Medicine Lodge Creek. The North Dakota pastures were $6 \mathrm{~km}$ south of Bismark $\left(100^{\circ} 48^{\prime} \mathrm{W}, 46^{\circ} 45^{\prime} \mathrm{N}\right)$ on bottomland beside the Missouri River. The alternative forages were primarily crested wheatgrass (Agropyron cristatum (L.) Gaertn.) in Idaho and smooth brome (Bromus inermis Leyss.) in North Dakota. The trial was designed to test for differences in leafy spurge utilization and preference with the main effects of location (Idaho and North Dakota) and origin of sheep (Idaho and North Dakota). Ten yearling non-lactating female sheep from each state were placed on small, leafy spurge-infested pastures in southeastern Idaho and central North Dakota. All sheep had previous experience grazing leafy spurge in their state of origin before the trial began. All sheep grazed the Idaho pastures in early June then these sheep were transported to North Dakota where they grazed the pastures in mid-June.

At each location, 4 replicate pastures were grazed by sheep from Idaho and 4 were grazed by sheep from North Dakota. Sheep from the 2 states were pastured separately. Pasture size was $20 \times 40 \mathrm{~m}$ in Idaho and $20 \times 20 \mathrm{~m}$ in North Dakota. Five sheep were grazed in each pasture for 4 days in Idaho and 5 days in North Dakota. Four pastures ( 2 per origin of sheep) were grazed first until approximately $50 \%$ of the total standing crop was consumed, then the sheep were moved to the next set of 4 pastures. This design helped ensure that the number of sheep in each pasture was adequate for normal behavior while providing sufficient pasture replication to detect treatment effects.

The soil at the Idaho site was a gravelly loam and the soil at the North Dakota site was a sandy loam. Soil analysis was conducted by the Soil Testing and Plant Analysis Laboratory at South Dakota State University following their standard procedures (1995). The characteristics of these soils are described in Table 1.

\begin{tabular}{|c|c|c|}
\hline & \multicolumn{2}{|c|}{ Location } \\
\hline & Idaho & North Dakota \\
\hline & \multicolumn{2}{|c|}{-----------(ppm)----------- } \\
\hline $\mathrm{NO}_{3}-\mathrm{N}(0-1.0)$ & 0.79 & 1.3 \\
\hline $\mathrm{P}(0-0.9 \mathrm{~m})$ & 24 & 2 \\
\hline $\mathrm{K}(0-0.9 \mathrm{~m})$ & 156 & 159 \\
\hline & ---------- & -(\%)---------- \\
\hline $\begin{array}{r}\text { Rock fragments } \\
\qquad(>2 \mathrm{~mm})\end{array}$ & $25-70$ & 0.00 \\
\hline
\end{tabular}

Standing crop was measured by clipping 5 randomly located $0.5 \mathrm{~m}^{2}$ plots in each pasture at the beginning, middle and end of grazing. The number of grazed and non-grazed spurge stems were counted in 10 permanently marked, randomly located $0.25 \mathrm{~m}^{2}$ plots per pasture at the beginning, middle and end of grazing. Percent utilization of leafy spurge stems was analyzed with the GLM procedure of SAS (1988) using a repeated measures design. The main effects were sheep origin and trial location (between experimental unit effects). Time of stem counting during the grazing period (middle and end) for each pasture was the repeated measure. The 4 replicate pastures were the experimental units and individual plot data were averaged for each pasture before statistical analysis.

Diet selection by sheep in each pasture was determined using the bite count technique and electronic data loggers (Sanders et al. 1980, Walker et al. 1992). All animals were observed while grazing using a focal animal sampling procedure (Altman 1974). Observations lasted 3 minutes per animal and multiple observations were made on each animal with the restriction that each animal in a pasture was observed once before an animal was observed another time. One observer recorded bites in each pasture. Bites were classified as leafy spurge, other forb, grass, or shrub. Bite count data were collected at the beginning and middle of the grazing time for each pasture but not at the end because we were interested in determining the extent to which the sheep would select leafy spurge when alternative vegetation was still available. Multiple 
observations for each animal at each time period (beginning and middle ) in a pasture were averaged and then means for each animal by time period across pastures were calculated before further analysis. Bite count data were summarized in this manner because of missing data resulting from difficulties in observing sheep and some equipment malfunction. Because of missing data, bite count data were analyzed using individual sheep as experimental units. Preference for different forage classes was calculated as the difference between the percent of a class in the diet and the percent of that class in the available herbage (Strauss 1979). This is a normally distributed linear index with a range of preference and avoidance from +100 to -100 centered on 0 (for random feeding). Bite count data were analyzed with the GLM procedure of SAS (1988) for the main effects of sheep origin, trial location, time during grazing period and their interactions. Origin of sheep was a between animal effect while trial location and period of trial were within animal repeated measures.

Leafy spurge used for nutritional analysis for all trials was dried and ground to pass a 1-mm screen before analysis for Kjeldahl N (AOAC 1990) and nonsequential neutral detergent fiber (NDF) and acid detergent fiber (ADF) (Goering and Van Soest 1970). The percentages of crude protein (CP), NDF and ADF in samples are expressed on a dry matter basis.

\section{Trial 2}

This trial was conducted in pens with leafy spurge harvested from near the Idaho and North Dakota sites for Trial 1. A different group of sheep were used from those used in the first trial. Leafy spurge was in seed-ripening and seed-ripe growth stages when harvested at both sites and was airdried and chopped to about 2-cm-long pieces.

During a 3-day pre-trial period, 8 adult white-faced wethers from Idaho were placed in individual pens (ca. 1.5 $\mathrm{m}^{2}$ ) and offered water 24 hours $\bullet$ day $^{-1}$ and alfalfa pellets between 0800 and 1800 hours in 2 adjacent feed boxes in each pen. The wethers had no previ- ous experience with leafy spurge. Following the pre-trial period, consumption of Idaho and North Dakota leafy spurge by each wether was measured in a 2-day trial by placing leafy spurge from each state into the 2 adjacent feed boxes in each pen. Placement of the Idaho and North Dakota leafy spurge into the feed boxes was reversed on the second day of the trial. During the trial, the sheep had ad libitum access to water and were allowed to eat as much of the 2 leafy spurge types as they desired from 0800 to 1800 hours each day. They only had leafy spurge to eat during this trial. Intakes of the 2 leafy spurge types were compared by repeated measures analysis of variance (SAS 1988) with origin of leafy spurge a between animal effect and day of trial a within animal repeated measure.

\section{Trial 3}

The third trial was a pen trial in which sheep were offered Idaho leafy spurge that grew from soil that was or was not fertilized. In April, before the growing season began, a $500 \mathrm{~m}^{2}$ area of leafy spurge-infested land was fertilized at the Idaho site (described by Walker et al. 1994). The site was fertilized at a rate of $300 \mathrm{~kg} \bullet \mathrm{ha}^{-1}$ with a mixture composed of $24 \%$ urea nitrogen $(4.2 \%$ of this was coated slowrelease nitrogen), $4 \%$ ammonia nitrate, $4 \%$ phosphoric acid, $8 \%$ soluble potash $\left(\mathrm{K}_{2} 0\right)$, $4 \%$ sulfur and $1 \%$ iron. Three months after the area was fertilized, leafy spurge was harvested from the site when it was primarily in seedripening and seed-ripe growth stages. Leafy spurge from an adjacent but unfertilized area with similar soil was also harvested at this time. Leafy spurge from both the fertilized and unfertilized sites was air-dried and chopped to 2-cm-long pieces.

In a 5-day pre-trial period, 10 weaned lambs with no previous exposure to leafy spurge were trained to eat alfalfa pellets from 2 adjacent feed boxes in individual $\left(1.5 \mathrm{~m}^{2}\right)$ pens. During the 4-day trial period, lambs were placed in individual pens between 0800 and 1600 hours and each lamb's consumption of fertilized and unfertilized leafy spurge was measured. The location of the 2 leafy spurge types was alternated between left and right feed boxes. During the test period, the sheep had ad libitum access to water and were allowed to eat as much of the 2 leafy spurge types as they desired from 0800 until 1600 hours each day. They were offered only leafy spurge to eat during the trial period. Intakes of the 2 leafy spurge types were compared over days by repeated measures analysis of variance (SAS 1988).

\section{Results and Discussion}

\section{Trial 1}

When grazing began, grass comprised 61 and $74 \%$ of the standing crop in Idaho and North Dakota, respectively, whereas leafy spurge represented 30 and $24 \%$ of the standing crop in Idaho and North Dakota, respectively. Percent of leafy spurge stems grazed (Fig. 1) differed between locations $(P=0.002)$, period of trial $(P$ $=0.0001)$, and the location $X$ origin of sheep interaction was significant $(\mathrm{P}=$ 0.06). Sheep origin did not affect percent of leafy spurge stems grazed $(\mathrm{P}=$ $0.33)$, and all other interactions were not significant $(\mathrm{P}>0.20)$. The effect of period (first half vs. second half) was simply an indication that utilization of leafy spurge increased as the trial progressed. The location $\mathrm{x}$ origin of sheep interaction $(\mathrm{P}=0.06)$ resulted from a reversal of percent utilization of spurge stems by Idaho and North Dakota sheep in Idaho and North Dakota (Fig. 1). Idaho sheep had the lowest utilization in Idaho and the highest utilization in North Dakota. An explanation for this reversal is not apparent. Of greatest importance to this study was the significantly greater percent utilization of leafy spurge stems in North Dakota $(100 \%)$ compared to Idaho $(70 \%)$.

Preference for leafy spurge (Fig. 2) was not influenced by origin of sheep $(\mathrm{P}=0.14)$, but it was affected by location of grazing $(\mathrm{P}=0.003)$, grazing period $(\mathrm{P}=0.005)$, and interactions of grazing period with origin of sheep $(\mathrm{P}$ $=0.002)$ and location $(\mathrm{P}=0.01)$ and 


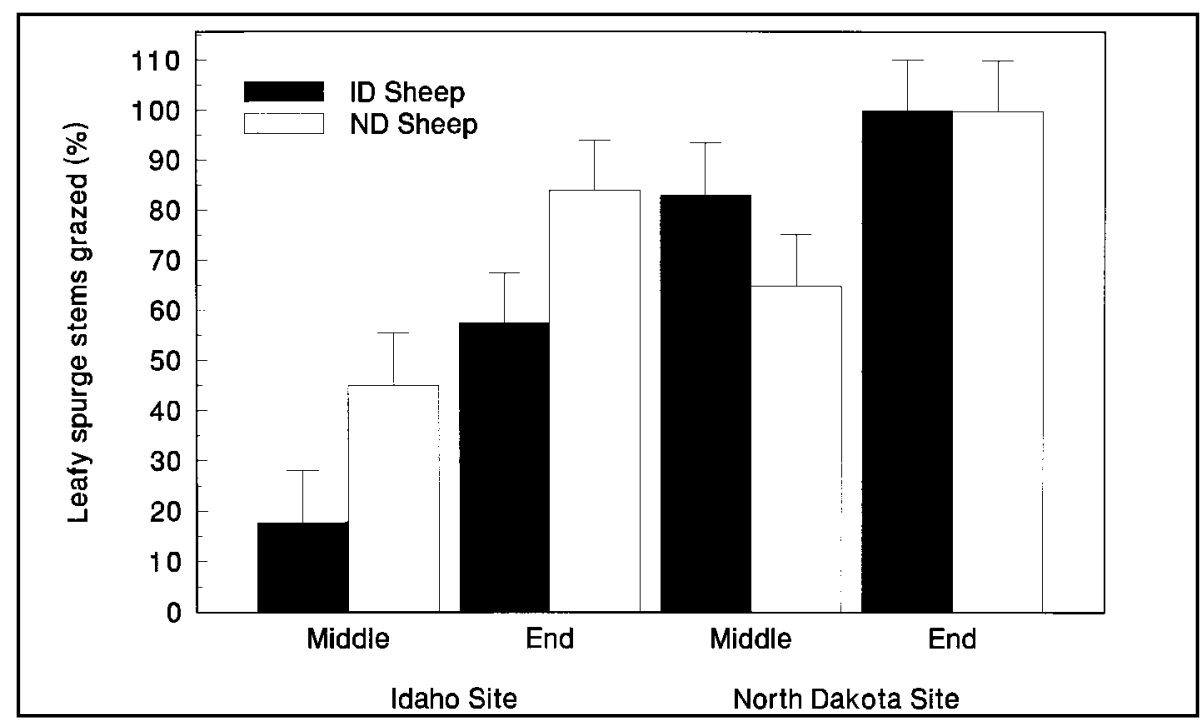

Fig. 1. Percentage of leafy spurge stems grazed at the middle and end of grazing trials in Idaho and North Dakota by sheep that originated from Idaho or North Dakota. Bars represent the standard error of the least squares mean.

by the 3-way period $\times$ origin $\times$ location interaction $(\mathrm{P}=.04)$. We believe the period $X$ origin $X$ location interaction shows the effect of learning on diet selection. This interaction was a result of the initial preference by North Dakota sheep for leafy spurge during the beginning time period in the first set of Idaho pastures. We suspect that this was due to their previous positive post-ingestive experiences with leafy spurge in North Dakota. Relative to the objectives of this study, the significant effect of location was the most important result of the analysis of sheep preference for leafy spurge. In Idaho, sheep grazed leafy spurge reluctantly while in North Dakota sheep consumed leafy spurge in proportion to its availability.

\section{Trial 2}

The sheep ate much more $(\mathrm{P}=$ $0.0001)$ of the leafy spurge from North Dakota (609 and $761 \mathrm{~g}$ on days 1 and 2, respectively) than from Idaho (148 and $82 \mathrm{~g}$ on days 1 and 2, respectively). These results were consistent with those from the first trial. The low relative palatablility of the Idaho spurge is also consistent with results from grazing trials in Idaho, which were conducted close to where spurge for Trial 2 was collected and where sheep grazed leafy spurge reluctantly (Walker et al. 1994). Crude protein expected the Idaho leafy spurge to have been preferred by the sheep. Sheep preference for the North Dakota spurge apparently resulted from some other characteristic(s) and we suggest this was lower levels of aversive chemicals in the North Dakota leafy spurge.

\section{Trial 3}

The sheep ate similar $(\mathrm{P} \geq .68)$ amounts of leafy spurge from the fertilized and non-fertilized sites on the first 2 days of the trial (Fig. 3). However, their consumption of spurge from the fertilized site was greater on the third $(\mathrm{P}=.06)$ and fourth $(\mathrm{P}=.01)$ days of the trial (Fig. 3). The feeding behavior of the sheep suggests that they gradually learned to reduce their consumption of the non-fertilized leafy spurge and increase their consumption of the fertilized leafy spurge. Their feeding behavior was consistent with the learning model of ruminant diet selection in respect to aversive phytochemicals (Provenza 1995).

Crude protein levels in leafy spurge from the fertilized and non-fertilized sites were 12.2 and $13.3 \%$, respectively. Neutral detergent fiber levels were 42.5 and $37.3 \%$ for the fertilized and non-fertilized leafy spurge, respectively, and ADF levels were 35.6 and $31.3 \%$ for the fertilized and non-fertilized spurge, respectively. Thus, there is no evidence from these data that the

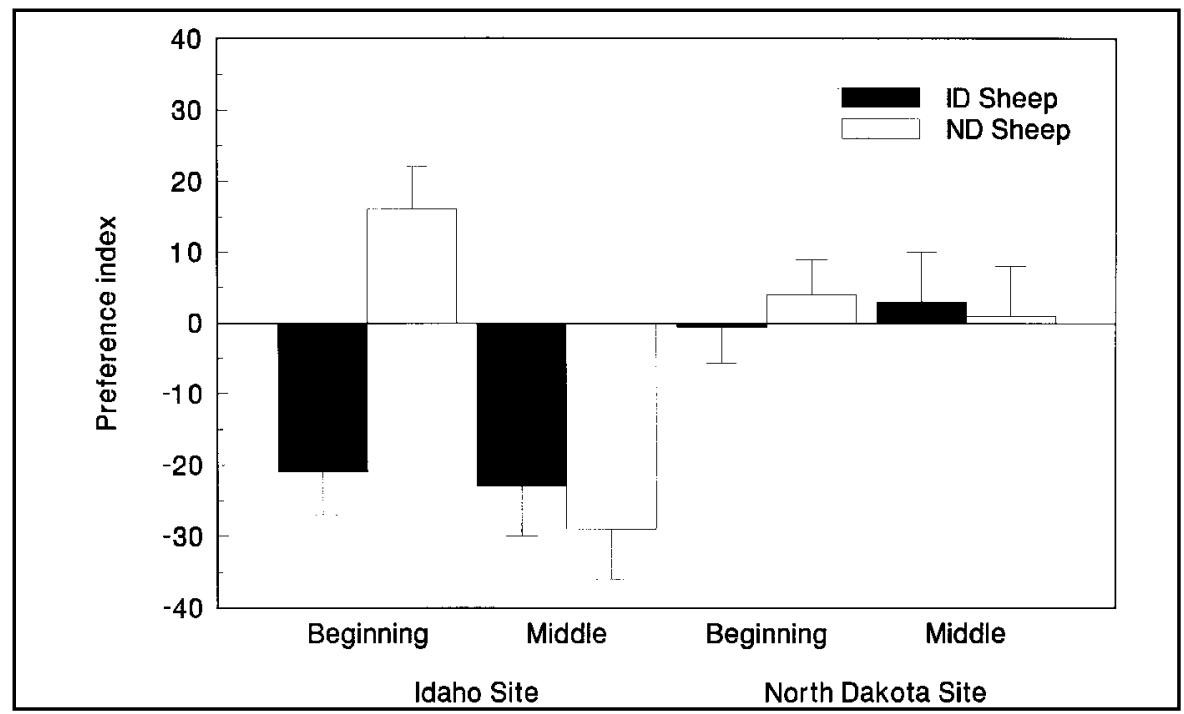

Fig. 2. Strauss' index of preference (\% spurge in diet \% spurge in standing crop) for leafy spurge at the beginning and middle of grazing trials in Idaho and North Dakota by sheep that originated from Idaho or North Dakota. Bars represent the standard error of the least squares mean. 


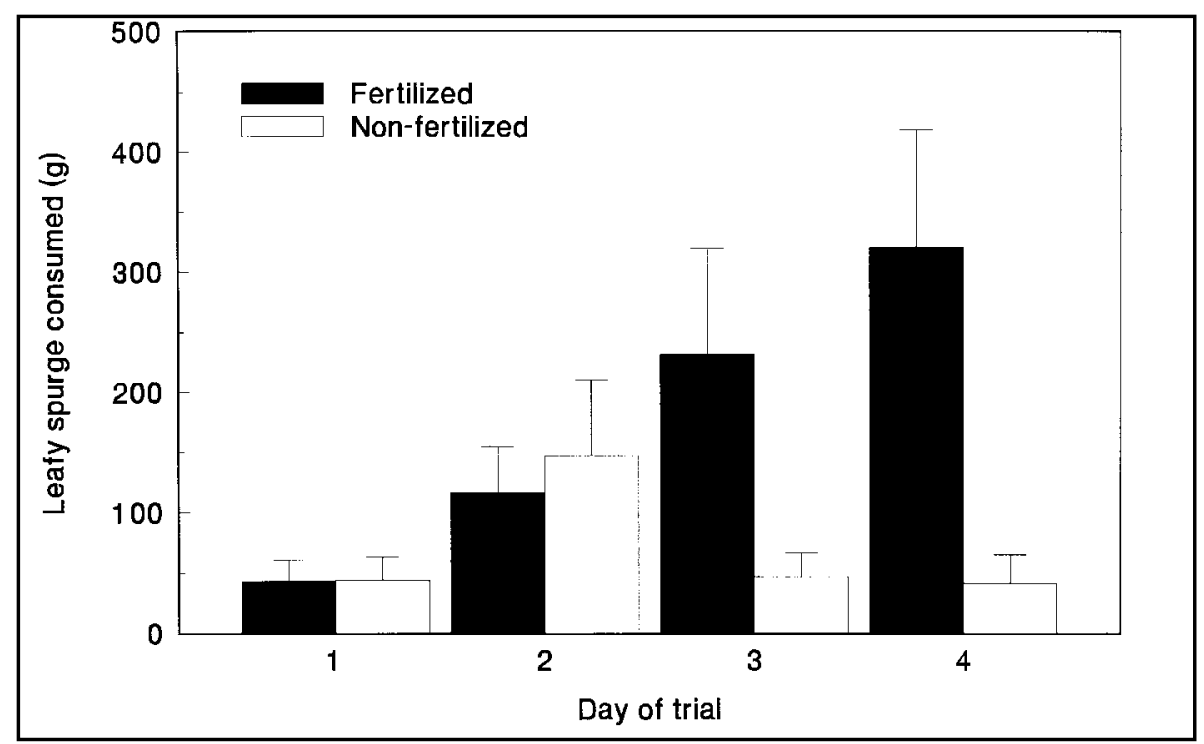

Fig. 3. Air-dried leafy spurge consumed by sheep on the 4 days of Trial 3 . The leafy spurge was harvested from fertilized and non-fertilized sites near the Idaho pasture used in Trial 1. Bars represent the standard error of the mean.

sheep developed a preference for the fertilized spurge because it offered them greater levels of $\mathrm{CP}$ or lower levels of fiber.

There is considerable supporting evidence for the carbon-nutrient balance hypothesis, which suggests that carbon-based phytochemicals will accumulate in plant tissues when low nutrient uptake limits plant growth more so than does photosynthesis (Bryant et al. 1983, 1991, Mihaliak and Lincoln 1985, Mihaliak et al. 1987, Fajer et al. 1992, Ruohomki et al. 1996). We suspect that the leafy spurge collected from the non-fertilized site had higher levels of aversive carbon-based phytochemicals than did the leafy spurge collected from the fertilized site.

\section{Conclusions}

Different preferences of sheep for leafy spurge from sites in Idaho and North Dakota appears to result from differences in the leafy spurge growing on these sites rather than from differences in the sheep. We have 2 reasons to suspect that the differences in leafy spurge on these sites is more likely a function of differences in growing conditions than of genetic differences between colonies of leafy

\section{Literature Cited}

Altman, J. 1974. Observational study of behavior: sampling methods. Behav. 49:227-265.

AOAC. 1990. Official Methods of Analysis (15th Ed.). Assoc. of Official Anal. Chem., Arlington. Virg.

Bartz, S., B. Landgraf, P. Fay, and K. Havstad. 1985. Leafy spurge (Euphorbia esula) as a forage component for ewes and lambs. SID Res. Digest, Winter, p. 39-42.

Briske, D.D. and B.J. Camp. 1982. Water stress increases alkaloid concentrations in threadleaf groundsel (Senecio longilobus). Weed Sci. 30:106-108.

Bryant, J.P., F.S. Chapin, III, and D.R. Klein. 1983. Carbon/nutrient balance of boreal plants in relation to vertebrate herbivory. Oikos 40:357-368.

Bryant, J.P., P.J. Kuropat, P.B. Reichardt, and T.P. Clausen. 1991. Controls over the allocation of resources by woody plants to chemical antiherbivore defense. p. 83-102 In: R.T. Palo, and C.T. Robbins (eds.) Plant defenses against mammalian herbivory. CRC Press, Boca Raton, Fla.

Fajer, E.D., M.D. Bowers, and F.A. Bazzaz. 1992. The effect of nutrients and enriched $\mathrm{CO}_{2}$ environments on production of carbon-based allelochemicals in Plantago: a test of the carbon/nutrient balance hypothesis. Amer. Natur. 140:707-723.

Faller, T.C., P. Berg, K. Ringwall, and D. Nudell. 1995. Management strategies to effectively control leafy spurge in rangeland by grazing sheep. p. 25-27 In: 36th Ann. Sheep Day, Rep. 36, North Dakota State Univ., Hettinger Res. Ext. Ctr., Hettinger, N.D.

Goering, H.K. and P.J. Van Soest. 1970. Forage fiber analyses (apparatus, reagents, procedures, and some applications). Agr. Handb. 379. ARS, USDA, Washington, D.C.

Johnston, A. and R.W. Peake. 1960. Effect of selective grazing by sheep on the control of leafy spurge (Euphorbia esula L.). J. Range Manage. 13:192-195.

Kronberg, S.L., J.W. Walker, and C.D. Cheney. 1994. Learning as a proximate causal mechanism of feeding niche separation in sympatric herbivores. p. 28 In: Abstr. 47th Ann. Meeting Soc. Range Manage.

Kronberg, S.L., W.C. Lynch, C.D. Cheney, and J.W. Walker. 1995. Potential aversive compounds in leafy spurge for ruminants and rats. J. Chem. Ecol. 21:1387-1399.

Kronberg, S.L., R.B. Muntifering, E.L. Ayers, and C.B. Marlow. 1993. Cattle avoidance of leafy spurge: a case of conditioned aversion. J. Range Manage. 46:364-366. 
Landgraf, B.K., P.K. Fay, and K. Havstad. 1984. Utilization of leafy spurge (Euphorbia esula) by sheep. Weed Sci. 32:348-352.

Mihaliak, C.A. and D.E. Lincoln. 1985. Growth pattern and carbon allocation to volatile leaf terpenes under nitrogen-limiting conditions in Heterotheca subaxillairis. Oecologia (Berlin) 66:423-426.

Mihaliak, C.A., D. Couvet, and D.E. Lincoln. 1987. Inhibition of feeding by a generalist insect due to increased volatile leaf terpenes under nitrate-limiting conditions. J. Chem. Ecol. 13:2059-2067.

Nissen, S.J., R.A. Masters, D.J. Lee, and M.L. Rowe. 1992. Comparison of restricted fragment length polymorphisms in chloroplast DNA of five leafy spurge (Euphorbia spp.) accessions. Weed Sci. 40:63-67.

Olson, B.E., R.T. Wallander, and K.M. Olson-Rutz. 1995. Effect of previous experience on sheep grazing leafy spurge. p. 45 In: Abstr. 48th Ann. Meeting Soc. Range Manage.
Provenza, F.D. 1995. Postingestive feedback as an elementary determinant of food selection and intake in ruminants. J. Range Manage. 48:2-17.

Provenza, F.D., J.A. Pfister, and C.D. Cheney. 1992. Mechanisms of learning in diet selection with reference to phytotoxicosis in herbivores. J. Range Manage. 45:36-45.

Ruohomki, K., F.S. Chapin, III, E. Haukioja, S. Neuvonen, and J. Suomela. 1996. Delayed inducible resistance in mountain birch in response to fertilization and shade. Ecol. 77:2302-2311.

Sanders, K.D., B.E. Dahl, and G. Scott. 1980. Bite-count vs fecal analysis for range animal diets. J. Range Manage. 33:146-149.

SAS. 1988. SAS/STAT User's Guide, release 6.03. SAS Inst. Inc., Cary, N. C.

South Dakota State Soil Testing and Plant Analysis Laboratory. 1995. Soil testing procedures. S.D. Agr. Exp. Sta. Plant Sci. Pamphlet 81.
Squibb, R.C., F.D. Provenza, and D.F. Balph. 1990. Effect of age of exposure on consumption of a shrub by sheep. J. Anim. Sci. 68:987-997.

Strauss, R.E. 1979. Reliability estimates for Ivlev's electivity index, the forage ratio, and a proposed linear index of food selection. Trans. Amer. Fish Soc. 108:344-352.

Vrieling, K., H. de Vos, and C.A.M. van Wijk. 1993. Genetic analysis of the concentrations of pyrrolizidine alkaloids in Senecio jacobaea. Phytochemistry 32:1141-1144.

Walker, J.W., K.J. Hemenway, P.G. Hatfield, and H.A. Glimp. 1992. Training lambs to be weed eaters: Studies with leafy spurge. J. Range Manage. 45:245-248.

Walker, J.W., S.L. Kronberg, S.L. AlRowaily, and N.W. West. 1994. Comparison of sheep and goat preferences for leafy spurge. J. Range Manage. 47:429-434. 